\title{
BRONZE AND IRON
}







UNIVERSITY OF CALIFORNIA PRESS BERKELEY L OS ANGELES LONDON 1973 
UNIVERSITY OF CALIFORNIA PRESS

BERKELEY AND LOS ANGELES, CALIFORNIA

UNIVERSITY OF CALIFORNIA PRESS, LTD.

LONDON, ENGLAND

COPYRIGHT (C) 1973 BY THE REGENTS OF THE UNIVERSITY OF CALIFORNIA

ISBN : 0-520-02164-9

LIBRARY OF CONGRESS CATALOG CARD

NUMBER : 71-182274

PRINTED IN THE UNITED STATES OF AMERICA

DESIGNED BY DAVE COMSTOCK

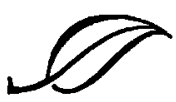




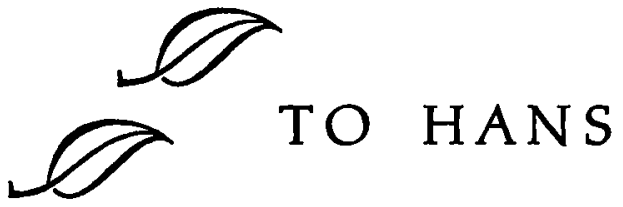

$\mathscr{\sigma}$

yes 
